Эксперт Российского общественного института избирательного права Красинский Владислав Вячеславович

Источник опубликования: Красинский $B . B$. Угрозы национальной безопасности России, возникающие при организации и проведении выборов, в аспекте правовой культуры // Проблемы правовой и криминологической культуры борьбы с преступностью. М.: Российская криминологическая ассоциация, 2002. С. 18-21; www.krasinskiy.ru

\title{
Угрозы национальной безопасности России, возникающие в процессе организации и проведения выборов, в аспекте правовой культуры
}

Одной из существенных составляющих избирательного процесса в России, обеспечивающих законность его прохождения, реализацию избирательных прав и оказывающих заметное влияние на непосредственное осуществление гражданами России принадлежащей им власти, является правовая культура организации и проведения выборов. Поскольку выборы представляют собой политико-правовой институт непосредственного народовластия, было бы недостаточно корректным вести речь только о правовой культуре организации и проведения выборов, поэтому автор при анализе поставленной проблемы будет рассматривать правовую культуру неразрывно с политической.

Учитывая важность государственного регулирования и формирования единой государственной политики в области общественных отношений, возникающих в связи с организацией и проведением выборов, Указом Президента России 28 февраля 1995 года была утверждена Федеральная целевая программа повышения правовой культуры избирателей и организаторов выборов в Российской Федерации, включавшая перечень программных мероприятий на период с 1995 по 1999 годы. В настоящее время Правительством России введен в действие Комплекс мер по повышению профессиональной подготовки организаторов выборов и референдумов и правовому просвещению избирателей в Российской Федерации на 2000 - 2005 годы. Суть данного Комплекса мер сводится к постоянной и последовательной работе по правовому образованию и воспитанию граждан, повышению профессионализма организаторов выборов посредством реализации совокупности политических, правовых, финансовых, пропагандистских, организационных, методических мер, охватывающих полный цикл избирательных процедур и действий.

Практика проходящих в Российской Федерации избирательных кампаний свидетельствует, с одной стороны, о развитии демократических институтов и совершенствовании законодательства о выборах, а с другой стороны, о недостаточной правовой культуре избирателей, организаторов выборов и иных участников избирательного процесса, связанной, в частности, с их низкой политической активностью, индифферентностью к 
настойчивым попыткам проникновения представителей организованных преступных сообществ и групп в органы государственной власти и местного самоуправления, ростом преступных посягательств на избирательные права.

К возникающим в ходе избирательных кампаний угрозам национальной безопасности России, ее целостности, можно отнести следующие:

стремление ряда иностранных государств оказывать целенаправленное информационно-пропагандистское, финансовое и политическое воздействие на процесс организации и проведения выборов в ущерб интересам национальной безопасности России;

- попытки продвижения организованными преступными сообществами и группами своих кандидатов в органы государственной власти и местного самоуправления;

- нарушение субъектами Российской Федерации принципа верховенства Конституции России и федерального законодательства в сфере избирательных прав граждан, принятие федеральными органами государственной власти, органами государственной власти субъектов Федерации нормативных правовых актов, ущемляющих избирательные права граждан;

- противоправные посягательства, направленные на насильственное изменение конституционного строя, нарушение целостности Российской Федерации, совершение массовых беспорядков, действий, нарушающих равноправие граждан или возбуждающих социальную, расовую, национальную, религиозную вражду в процессе организации и проведения выборов, использование избирательных технологий манипулятивного воздействия на общественное мнение, носящие массовый характер финансовые злоупотребления в использовании избирательных фондов;

организационная, материальная, финансовая и техническая зависимость избирательных комиссий и территориальных подразделений федеральных органов исполнительной власти (в том числе правоохранительных органов) от руководителей субъектов Федерации в процессе организации и проведения выборов.

Росту угроз национальной безопасности в процессе организации и проведения выборов в Российской Федерации способствует ряд факторов. К ним относятся как общие, так и специфические факторы. В группу общих факторов, оказывающих влияние на широкий круг общественных отношений, в том числе прямо не связанных с выборами, по мнению автора, входят: ослабление режима законности; недостаточное бюджетное финансирование; невысокая эффективность правоохранительной деятельности. Специфические факторы роста угроз национальной безопасности присущи непосредственно процессу организации и проведения выборов в Российской Федерации. Среди них можно выделить: несовершенство нормативной правовой базы, регулирующей отношения в области обеспечения национальной безопасности в процессе организации и проведения выборов; недостаточную координацию деятельности федеральных органов государственной власти, органов 
государственной власти субъектов России по формированию и реализации единой государственной политики в области обеспечения национальной безопасности; дефицит квалифицированных кадров в области обеспечения национальной безопасности в ходе выборов; низкую политическую и правовую культуру организации и проведения выборов.

Между тем, своевременный учет указанных факторов, предупреждение и нейтрализация возникающих угроз возможны лишь при условии согласованного функционирования, взаимодействия и сотрудничества всех органов государственной власти, общественных организаций и граждан Российской Федерации в рамках правового пространства. К сожалению, в настоящее время продолжает складываться тревожная ситуация, при которой в обществе отсутствует правовой механизм воздействия на власть, принимаемые нормативные акты не действуют, а бессистемно осуществляемые государственными органами инициативы оказываются не подкрепленными реальным содержанием. В качестве примера можно привести упомянутую выше Федеральную целевую программу, о существовании которой общественность почти ничего не знает. Большая часть перечня включенных в нее программных мероприятий носит декларативный характер и практически не выполняется.

Важной проблемой также является фактическая отстраненность граждан от участия в управлении делами государством; слабая информированность общества о деятельности избирательных объединений, кандидатов на выборные должности, в том числе на предмет соответствия ее действующему законодательству; о типичных правонарушениях в процессе организации и проведения выборов; о предпринимаемых избирательными комиссиями и правоохранительными органами мерах по выявлению, предупреждению и пресечению противоправных посягательств, что прямо сказывается на реализации и защите политических прав граждан.

В соответствии с этим, правовая культура организации и проведения выборов с позиций обеспечения национальной безопасности может рассматриваться двояко: во-первых, как состояние правосознания, материализованные юридические ценности и юридически значимое поведение людей, связанное с восприятием участниками избирательного процесса угроз национальной безопасности, возникающих в ходе выборов; во-вторых, как предпосылка эффективной деятельности по обеспечению национальной безопасности в процессе организации и проведения выборов.

В свою очередь, деятельность правоохранительных органов по нейтрализации возникающих в период выборов угроз национальной безопасности станет гораздо более результативной, если организаторы и другие участники выборов будут на всех стадиях избирательного процесса строго придерживаться правовых предписаний, знать и ценить законы, постоянно повышать свою политико-правовую культуру.

В структуре правовой культуры организации и проведения выборов можно условно выделить четыре основных элемента: правовую культуру организаторов выборов; правовую культуру избирателей (граждан России и в 
предусмотренных законодательством

случаях иностранных граждан); правовую культуру представителей средств массовой информации, избирательных объединений (блоков), кандидатов, их доверенных лиц, наблюдателей; правовую культуру иных участников избирательного процесса (государственных и муниципальных служащих, сотрудников правоохранительных органов, оказывающих содействие избирательным комиссиям). В основе предложенной классификации лежит целеполагание и роль той или иной категории участников избирательного процесса в выборной кампании.

Укрепления национальной безопасности, снижения потенциала угроз, возникающих в процессе организации и проведения выборов можно добиться путем стимулирования прогрессивного развития правовой культуры и целенаправленного воздействия на ее соответствующие структурные элементы. Исходя из изложенного, представляется возможным рассмотреть ряд направлений развития правовой культуры организации и проведения выборов в Российской Федерации.

Первое. Повышение профессиональной правовой культуры организаторов выборов должно быть направлено на формирование требовательного отношения к неукоснительному соблюдению установленной законом процедуры избирательных действий, создание непримиримого отношения указанной категории участников выборов к возможным правонарушениям в процессе организации и проведения выборов, обеспечение взаимной ответственности государства и личности в избирательном процессе. Этому могло бы способствовать укрепление независимости избирательных комиссий от региональных и местных властей, реализация гарантий, обеспечивающих высокий статус членов избирательной комиссии, проведение регулярных занятий с должностными лицами избирательных комиссий всех уровней по подготовке к принятию оперативных решений и деятельности в условиях острой нехватки времени на осуществление тех или иных избирательных действий в нестандартных ситуациях, глубокое изучение действующего отечественного и зарубежного законодательства о выборах.

Второе. Развитие правовой культуры избирателей должно преследовать цели повышения политической активности граждан в избирательном процессе, широкого использования предоставленных им прав и свобод в политической сфере, формирования осознанной необходимости и готовности оказывать содействие правоохранительным органам в выявлении, предупреждении и пресечении правонарушений (в том числе, в рассматриваемой области). Следует активно готовить и проводить учебнообразовательные, просветительские, информационные программы в школах, вузах, средствах массовой информации, формировать устойчивый интерес избирателей к выборам.

Третье. Правовую культуру представителей средств массовой информации, избирательных объединений (блоков), кандидатов, их доверенных лиц, наблюдателей представляется необходимым повышать в 
процессе изучения законодательства о выборах и подготовки к практическому овладению навыков его применения, обучения квалифицированному ведению избирательных кампаний на основе организации правовых консультаций и соответствующих курсов при избирательных комиссиях. Следовало бы усилить ответственность организаций теле- и радиовещания и периодических печатных изданий за использование технологий манипулятивного воздействия на общественное мнение. Напротив, распространение в средствах массовой информации объективных материалов о деятельности избирательных комиссий, других участников избирательного процесса образует важнейший элемент доверия граждан к собственному государству.

Четвертое. Правовую культуру иных участников избирательного процесса (государственных и муниципальных служащих, сотрудников правоохранительных органов, оказывающих содействие избирательным комиссиям) целесообразно развивать в направлении непредвзятого и беспристрастного содействия работе избирательных комиссий, недопустимости непосредственного вовлечения в избирательный процесс, ущемления гарантированных конституцией прав и свобод граждан, законности прохождения избирательных кампаний.

Особое место в процессе повышения правовой культуры организации и проведения выборов должно отводиться изучению наиболее типичных нарушений законодательства о выборах, обобщению прокурорскоследственной и судебной практики в рассматриваемой области, совершенствованию нормативной правовой базы, регулирующей отношения в области обеспечения национальной безопасности в процессе организации и проведения выборов, подготовке высококвалифицированных специалистов в области обеспечения национальной безопасности в ходе выборов. 